\title{
Relationship between serum insulin autoantibodies, islet cell antibodies and Coxsackie-B4 and mumps virus-specific antibodies at the clinical manifestation of Type 1 (insulin-dependent) diabetes
}

\author{
J. Karjalainen' ${ }^{1}$ M. Knip ${ }^{1}$, H. Hyöty ${ }^{3}$, P. Leinikki ${ }^{3}$, J. Ilonen², M.-L. Käär ${ }^{1}$ and H. K. Åkerblom ${ }^{4}$ \\ ${ }^{1}$ Department of Paediatrics, University of Oulu, ${ }^{2}$ National Public Health Institute, Oulu, ${ }^{3}$ Institute of Biomedical Sciences, \\ University of Tampere, Tampere, and ${ }^{4}$ The Children's Hospital, II Department of Paediatrics, University of Helsinki, Helsinki, Finland
}

Summary. In order to elucidate the possible relationship between insulin autoantibodies (IAA), conventional (ICA-IgG) and complement-fixing (CF-ICA) islet cell antibodies and Coxsackie-B4 and mumps virus-specific antibodies (IgG, IgM and IgA classes), we studied 194 children and adolescents with newly diagnosed Type 1 (insulin-dependent) diabetes. Sixty-one (31.4\%) of the subjects were IAA-positive at diagnosis and $73.8 \%(45 / 61)$ of these also had ICA-IgG compared to $51.1 \%(68 / 113, p<0.01)$ of IAA-negative children. CF-ICA showed no significant association with IAA. The levels of IAA were significantly higher in the patients with ICA-IgG compared to those without $[5.9 \pm 1.6 \%$ (SEM) vs $2.5 \pm 0.3 \%, p<0.01]$. The patients positive for IAA were younger at diagnosis than the IAA-negative ones; $(7.1 \pm 0.5$ vs $9.3 \pm 0.3$ years, $p<0.001)$ and this was also true for ICAIgG-positive children $(8.1 \pm 0.4$ vs $9.4 \pm 0.5$ years, $p<0.05)$ in comparison to ICA-IgG-negative subjects. No significant associations were found between IAA or ICA on the one hand and a positive family history of Type 1 diabetes or metabolic derangements at diagnosis on the other. Subjects negative for ICA were more frequently positive for mumps virus specific
$\mathrm{IgG}$ antibodies than the ICA-positive patients (50/80 vs $53 / 111, p<0.05$ ), and Coxsackie-B4 virus-specific IgA antibodies were more common in the CF-ICA-negative than the CF-ICA-positive children $(53 / 111$ vs $29 / 80, p<0.05)$. There was no association between the IAA levels and Coxsackie-B4 or mumps virus specific antibodies. However, patients with serological evidence of a recent mumps infection $(n=13)$ had higher IAA levels than the other children $(4.4 \pm 7.7 \%$ vs $2.8 \pm 1.4 \%, p<0.02)$. Our data suggest a positive association between IAA and ICA-IgG, supporting the view that IAA are like ICA serological markers of autoimmune $B$ cell damage. The inverse associations between autoantibodies and age and between ICA and viral antibodies support the hypothesis that autoimmune mechanisms may play a more crucial role in younger patients contracting Type 1 diabetes while environmental factors may be more important in older ones.

Key words: Type 1 (insulin-dependent) diabetes, insulin autoantibodies, islet cell antibodies, viral antibodies.

ICA) [18] in newly diagnosed subjects or in individuals with an increased risk of contracting the disease [15]. The interrelation between these humoral autoantibodies and signs of viral infections at the presentation of Type 1 diabetes and their possible association with high risk HLA-antigens are poorly documented. We therefore decided to evaluate the relationship between IAA, ICA, Coxsackie-B4 virus-specific and mumps virus-specific antibodies of the $\operatorname{IgG}, \operatorname{IgM}$ and $\operatorname{IgA}$ classes and certain high risk HLA-antigens in a large group of children and adolescents with newly diagnosed Type 1 diabetes.

\section{Subjects and methods}

The original study population comprised 273 children and adolescents with newly diagnosed Type 1 diabetes who were admitted to the Departments of Paediatrics at five university hospitals in Finland insulin autoantibodies (IAA) and conventional ICA (ICA-IgG), [16, 18] or complement-fixing ICA (CF- 
between November 1980 and June 1983. Seventy-nine patients were, however, excluded because of no available serum samples for the analyses. These children did not differ from the 194 patients included in the study in any clinical or biochemical parameters at the time of diagnosis. Twenty-four subjects were admitted to the Children's Hospital, University of Helsinki, 62 to the Department of Paediatrics, University of Turku, 43 to the Department of Paediatrics, University of Tampere, 24 to the Department of Paediatrics, University of Kuopio, and the remaining 41 to the Department of Paediatrics, University of Oulu for initiation of treatment for classic acuteonset Type 1 diabetes. Five patients were also included in another study previously reported [18]. The mean age of the patients was $8.6 \pm 4.1$ ( $\pm \mathrm{SD}$ ) years (range 0.7-15.8 years). At admission, 53/175 $(30.3 \%)$ were ketotic and $65 / 175(37.1 \%)$ subjects had ketoacidosis (Ketostix in undiluted serum positive and $\mathrm{pH}<7.35$ ).

Clinical parameters included in the study were data on the duration of symptoms prior to diagnosis, preceding infections and the occurrence of previously diagnosed endocrine disease in the patient as well as of Type 1 diabetes in first-degree relatives. As symptoms were regarded those coming from hyperglycaemia (i.e. polyuria, polydipsia, polyphagia and information of weight loss and tiredness). In addition, absolute weight, estimated weight loss and the degree of consciousness were registered on admission. The first blood sample was taken at diagnosis except for the sample for HLA analysis, which was obtained within 2 weeks during the first hospitalisation. The second blood sample for virus-antibody titres was obtained 2 months after diagnosis. The laboratory analyses comprised blood glucose concentrations, capillary blood gas analysis, presence of ketone bodies in plasma and urine, insulin autoantibodies (IAA), conventional (ICA-IgG) and complement-fixing islet cell antibodies (CFICA), Coxsackie-B4 and mumps virus-specific antibodies (classes $\operatorname{IgG}, \operatorname{Ig} M$ and $\operatorname{Ig} A)$ and HLA typing.

Serum IAA were determined in the Research Laboratory, Department of Paediatrics, University of Oulu using a modification [21] of the method described by Palmer et al. [14]. The serum samples were first extracted with acid charcoal prior to the analysis to remove endogenous insulin. They were then incubated with mono- ${ }^{125} \mathrm{I}$ (Tyr A 14)- human insulin (specific activity $200-300 \mathrm{mCi} / \mathrm{mg}$; Novo Research Institute, Bagsvaerd, Denmark) for $20 \mathrm{~h}$, after which the free and bound insulin fractions were separated using polyethylene glycol (PEG). The bound radioactivity in the precipitate as a percentage of the total counts in the assay (approximately $20,000 \mathrm{cpm} /$ tube) expressed the amount of insulin autoantibodies. The mean nonspecific binding for 10 samples was $0.6 \%$ (range $0.6-0.7 \%$ ). The results were not corrected for nonspecific binding. The intra-assay coefficient of variation was lower than $5 \%$ and the interassay coefficient of variation lower than $8 \%$. Binding of monoiodinated human insulin was $1.54 \pm 0.29 \%$ (mean $\pm \mathrm{SD}$ ) in 68 non-diabetic children (range $0.6-2.8 \%$ ). If the binding in the serum of a diabetic child exceeded $2.8 \%$, the patient was considered IAA-positive.

Islet cell antibodies (ICA) were determined in the same laboratory by both the conventional indirect immunofluorescence (ICA-IgG) method and the complement fixation (CF-ICA) test [22]. Cryostat sections of 5 micrometre human snap frozen blood group 0 pancreatic tissue were used as a substrate. The substrate was stored at $-70^{\circ} \mathrm{C}$ prior to the assay and the sera at $-20^{\circ} \mathrm{C}$. The assay was performed using undiluted sera, and pooled human serum (NHS) diluted $1: 2$ with $0.9 \% \mathrm{NaCl}$ was used to obtain extra complement for the determination of CF-ICA. The NHS was stored for not more than 3 months at $-20^{\circ} \mathrm{C}$. Fluorescein-conjugated rabbit antihuman-IgG (Behringwerke AG, Marburg, FRG) diluted to 1:40 was used for the detection of IF-ICA and antihuman $\mathrm{C}_{3} \mathrm{C}$ (Behringwerke $\mathrm{AG}$ ) at the same dilution as the CF-ICA detector. All the microscopic analyses were performed by the same person. For evaluating the reproducibility of our assay samples from 20 subjects were studied 6-7 times repeatedly on a "blind basis" and no overlapping was found between positive and negative samples. Thus, the reproducibility of our assay is good.

IgG-, IgM- and IgA-class antibodies against Coxsackie-B4 and mumps virus were measured using an enzyme-linked immunosor- bent assay (ELISA) as previously described $[5,8]$ in the Laboratory of Virology, Institute of Biomedical Sciences, University of Tampere. The method has been continuously used for several years in the routine serology and proved to be reliable in distinguishing past infections from the recent ones. After incubating the test serum dilutions in antigen coated microtitre plates for $1 \mathrm{~h}$ at $37^{\circ} \mathrm{C}$, antihuman $\mathrm{IgG}$, IgM and IgA produced in rabbits (Dako Immunoglobulins, Copenhagen, Denmark) were incubated for $30 \mathrm{~min}$ at $37^{\circ} \mathrm{C}$ at dilutions of $1: 2,000-1: 6,000$. After washing, phosphatase conjugated anti-rabbit immunoglobulin produced in swine (Orion Diagnostica, Mankkaa, Finland) reacted with bound conjugates overnight at $4{ }^{\circ} \mathrm{C}$. The activities were expressed in arbitrary enzyme immuno units (EIU) relative to positive and negative reference sera. The limit for IgG positivity was set at 15 EIU and that for IgM and IgA positivity at 20 EIU.

The definition for recent Coxsackie-B4 and mumps infections was based on one of the following criteria: 1) patients with high ( $>50 \mathrm{EIU}$ ) IgM class EIU-titre with contemporaneously elevated IgG or IgA-titres; 2) those who had an increase exceeding 20 EIU in the titres of all or at least two antibody classes in a second blood sample obtained 2 months after the first one.

Serological typing for HLA-A, B, C antigens was carried out with a standard two-stage microlymphocytotoxicity test, while local homozygous typing cells were used for the determination of HLADw specificities in the National Public Health Institute, Oulu.

\section{Statistical analysis}

The results were evaluated statistically using crosstabulation and Chi square statistics, unpaired Student's t-test and parametric one-way analysis of variance for normally distributed variables, and, in the case of a skewed distribution, Spearman's rank correlation test, Mann-Whitney U-test and Kruskall-Wallis one-way analysis of variance. Analysis of co-variance was used to control for the effect of age on the results. Where not otherwise indicated, the results are quoted in the text as means \pm SEM.

\section{Results}

At diagnosis $61(31.4 \%)$ children had IAA in their sera. The median value for insulin binding in the IAA-positive children was $9.6 \%$ (range $2.9-60.4 \%$ ). Twenty-nine of the boys $(26.9 \%)$ had IAA compared with 32 of the girls $(37.2 \%)$. The mean age of the patients was lower in the IAA-positive group than in the negative group (Table 1). IAA did not show any significant association with the occurrence of other diagnosed endocrine disorders, a positive family history of Type 1 diabetes, the duration of symptoms before diagnosis, preceeding infections or in clinical condition and degree of metabolic derangement at diagnosis (Table 1). Subjects with the HLA-antigen A9 $(50 / 159)$ had lower IAA levels than those without $(2.7 \pm 0.3 \%$ vs $4.6 \pm 0.8 \%, p<0.05)$. The HLA haplotype A9Bw16 $(16 / 128)$ was also associated with decreased IAA levels $(2.6 \pm 0.2 \%$ vs $4.4 \pm$ $0.5 \%, p<0.05$ ). HLA-Dw4 tended to occur more often in children positive for IAA than in the IAA-negative individuals (Table 1).

Almost $75 \%$ of the IAA-positive subjects had ICAIgG in their sera, compared with only half of the IAAnegative ones (Table 1), and a similar trend could be 
Table 1. Clinical and laboratory characteristics in two groups of newly diagnosed diabetic children classified according to the presence or absence of insulin autoantibodies (IAA) in their sera (mean \pm SEM)

\begin{tabular}{|c|c|c|c|}
\hline & $\begin{array}{l}\text { IAA + } \\
(n=61)\end{array}$ & $\begin{array}{l}\text { IAA- } \\
(n=133)\end{array}$ & $\begin{array}{l}\text { Level of } \\
\text { significance }\end{array}$ \\
\hline Sex (male/female) & $29 / 32$ & $79 / 54$ & NS \\
\hline Age (years) & $7.1 \pm 0.5$ & $9.3 \pm 0.3$ & $p<0.001$ \\
\hline Duration of symptoms (weeks) & $2.5 \pm 0.3$ & $3.6 \pm 0.5$ & NS \\
\hline Blood glucose $(\mathrm{mmol} / \mathrm{l})$ & $22.4 \pm 1.3$ & $20.3 \pm 0.7$ & NS \\
\hline $\mathrm{pH}$ & $7.33 \pm 0.01$ & $7.33 \pm 0.01$ & NS \\
\hline Base excess (mmol/1) & $-7.8 \pm 1.1$ & $-6.6 \pm 0.7$ & NS \\
\hline Ketoacidosis, $n(\%)$ & $21 / 55(38.2)$ & $44 / 120(36.7)$ & NS \\
\hline ICA-IgG, $n(\%)$ & $45(73.8)$ & $68(51.1)$ & $p<0.01$ \\
\hline CF-ICA, $n(\%)$ & $32(52.5)$ & $52(39.1)$ & $\mathrm{NS}$ \\
\hline \multicolumn{4}{|c|}{ Coxsackie-B4 virus-specific antibodies } \\
\hline $\mathrm{IgG}>15$ EIU, $n(\%)$ & $34 / 60(56.7)$ & $73 / 131(55.7)$ & NS \\
\hline $\mathrm{IgM}>20 \mathrm{EIU}, n(\%)$ & $0 / 60(0.0)$ & $3 / 131(2.3)$ & NS \\
\hline $\operatorname{IgA}>20$ EIU, $n(\%)$ & $23 / 60(38.3)$ & $59 / 131(45.0)$ & NS \\
\hline \multicolumn{4}{|l|}{ Mumps virus-specific antibodies } \\
\hline $\operatorname{IgG}>15$ EIU, $n(\%)$ & $32 / 59(54.2)$ & $72 / 131(55.0)$ & NS \\
\hline $\operatorname{IgM}>20$ EIU, $n(\%)$ & $9 / 59(15.3)$ & $21 / 131(16.0)$ & NS \\
\hline $\mathrm{IgA}>20 \mathrm{EIU}, n(\%)$ & $14 / 59(23.7)$ & $31 / 131(23.7)$ & NS \\
\hline $\mathrm{Dw} 3 / \mathrm{x}, n(\%)$ & $7 / 53(13.2)$ & $17 / 106(16.0)$ & NS \\
\hline Dw $4 / \mathrm{x}, n(\%)$ & $21 / 53(39.6)$ & $38 / 106(35.8)$ & NS \\
\hline $\mathrm{Dw} 3 / \mathrm{Dw} 4, n(\%)$ & $12 / 53(22.6)$ & $15 / 106(14.2)$ & NS \\
\hline
\end{tabular}

ICA-IgG = conventional islet cell antibodies, $\mathrm{CF}-\mathrm{ICA}=$ complement-fixing islet cell antibodies, $\mathrm{NS}=$ not significant

Table 2. Clinical and laboratory characteristics (mean \pm SEM, unless otherwise indicated) in three groups of children with newly diagnosed Type 1 (insulin-dependent) diabetes classified according to islet cell antibody (ICA) status (ICA-IgG $=$ conventional ICA, CF-ICA $=$ complement-fixing ICA, IAA = insulin autoantibodies)

\begin{tabular}{|c|c|c|c|c|}
\hline & $\begin{array}{l}\text { Group I } \\
\text { ICA-IgG+ } \\
\text { CF-ICA+ } \\
(n=83)\end{array}$ & $\begin{array}{l}\text { Group II } \\
\text { ICA-IgG+ } \\
\text { CF-ICA- } \\
(n=31)\end{array}$ & $\begin{array}{l}\text { Group III } \\
\text { ICA-IgG- } \\
\text { CF-ICA- } \\
(n=80)\end{array}$ & $\begin{array}{l}\text { Level of } \\
\text { significance }\end{array}$ \\
\hline Sex (male/female) & $42 / 41$ & $17 / 14$ & $49 / 31$ & NS \\
\hline Age (years) & $8.1 \pm 0.4$ & $7.9 \pm 0.8$ & $9.4 \pm 0.5$ & $\begin{array}{l}\text { I vs III and II vs III, } \\
p<0.05\end{array}$ \\
\hline Duration of symptoms (weeks) & $3.1 \pm 0.5$ & $3.7 \pm 1.1$ & $3.3 \pm 0.5$ & NS \\
\hline Blood glucose $(\mathrm{mmol} / \mathrm{l})$ & $20.5 \pm 0.9$ & $21.9 \pm 1.7$ & $21.0 \pm 1.1$ & NS \\
\hline Capillary $\mathrm{pH}$ & $7.31 \pm 0.01$ & $7.35 \pm 0.01$ & $7.33 \pm 0.01$ & NS \\
\hline Base excess $(\mathrm{mmol} / \mathrm{l})$ & $-7.7 \pm 1.0$ & $-5.6 \pm 0.8$ & $-6.4 \pm 0.9$ & NS \\
\hline Ketoacidosis, $n(\%)$ & $32 / 71(45.1)$ & $11 / 30(36.7)$ & $22 / 74(29.7)$ & NS \\
\hline \multicolumn{5}{|c|}{ Coxsackie-B4 virus-specific antibodies } \\
\hline $\mathrm{IgG}>15 \mathrm{EIU}, n(\%)$ & $42 / 80(52.5)$ & $16 / 31(51.6)$ & $49 / 80(61.3)$ & NS \\
\hline $\mathrm{IgM}>20 \mathrm{EIU}, n(\%)$ & $0 / 80(0.0)$ & $1 / 31(3.2)$ & $2 / 80(2.5)$ & NS \\
\hline $\operatorname{IgA}>20 \mathrm{EIU}, n(\%)$ & $29 / 80(36.3)$ & $16 / 31(51.6)$ & $37 / 80(46.3)$ & $\begin{array}{l}\text { I vs II and III, } \\
p<0.05\end{array}$ \\
\hline \multicolumn{5}{|l|}{ Mumps virus-specific antibodies } \\
\hline $\mathrm{IgG}>15$ EIU, $n(\%)$ & $38 / 79(48.1)$ & $15 / 31(48.3)$ & $50 / 80(62.5)$ & $\begin{array}{l}\text { I and II vs III, } \\
p<0.05\end{array}$ \\
\hline $\operatorname{IgM}>20 \mathrm{EIU}, n(\%)$ & $12 / 79(15.2)$ & $6 / 31(19.4)$ & $12 / 80(15.0)$ & NS \\
\hline $\operatorname{IgA}>20 \mathrm{EIU}, n(\%)$ & $17 / 79(21.5)$ & $6 / 31(19.4)$ & $22 / 80(27.5)$ & NS \\
\hline $\mathrm{Dw} 3 / \mathrm{x}, n(\%)$ & $9 / 67(13.4)$ & $0 / 23(0.0)$ & $15 / 69(21.7)$ & II vs III, $p<0.05$ \\
\hline Dw4/x, $n(\%)$ & $27 / 67(40.3)$ & $10 / 23(43.5)$ & $22 / 69(31.9)$ & NS \\
\hline Dw3/Dw4, $n(\%)$ & $10 / 67(14.9)$ & $4 / 23(17.4)$ & $13 / 69(18.8)$ & NS \\
\hline
\end{tabular}

NS $=$ not significant

seen regarding the distribution of CF-ICA, although here the difference was not significant. No association was found between IAA and the Coxsackie-B4 virus and mumps virus-specific antibodies (Table 1). Thirteen subjects $(6.7 \%)$ had had a serologically confirmed mumps virus infection preceding the diagnosis of Type 1 diabetes and eight of these $(61.5 \%)$ were posi- tive for IAA. These subjects had higher IAA levels than the other 181 subjects $(4.4 \pm 7.7 \%$ vs $2.8 \pm 1.4 \%$, $p<0.02$ ). In contrast, no such association was observed in patients with a recent Coxsackie-B4 infection.

ICA-IgG was detected in 114 subjects $(58.8 \%)$, and 83 children $(42.8 \%)$ were also positive for CF-ICA. The 
ICA-positive patients were younger than the ICA-negative patients (Table 2). We did not find any differences between the ICA-positive and negative children in the other clinical data or in the degree of metabolic decompensation at diagnosis. The ICA-positive subjects had significantly higher IAA titres than the ICAnegative patients (Fig.1). The ICA-IgG-negative patients were positive for HLA-Dw3 (28/69 vs 23/90, $p<0.05)$ and had mumps virus specific IgG antibodies $(50 / 80$ vs $53 / 110, p<0.05$, Table 2$)$ more often than the ICA-IgG-positive patients. Coxsackie-B4 virus-specific IgA antibodies were more frequently found in CF-ICA-negative patients than in CF-ICA-positive subjects $(53 / 111$ vs $29 / 80, p<0.05)$. No relationship was observed between recent mumps or Coxsackie-B4 virus infection and the occurrence of ICA-IgG or CFICA.

Those positive for all three autoantibodies (IAA, ICA-IgG and CF-ICA) were considerably younger than the other patients (Table 3). These autoantibodies also occurred together more often in girls than in boys (Table 3). The subjects positive for all three types of autoantibodies were characterised by a shorter duration of the symptomatic period prior to diagnosis (Table 3). After adjustment for age this still held true.

Sixty-one cases were diagnosed in the spring (March-May), 38 in the summer (June-August), 49 in the fall (September-November) and 55 in the winter (December-February). No differences could be observed in the incidence of IAA, ICA-IgG and CF-ICA between these four seasons.

\section{Discussion}

The frequency of insulin autoantibodies (IAA) at diagnosis of Type 1 diabetes seems to be of the same magnitude in most previous studies [13-21], although some variation in the incidence $(16-50 \%)[14,20]$ has been reported. This may be in part a consequence of methodological differences $[14,15]$ and of an unequal age distribution in the study populations $[13,16,18]$, in view of the inverse relation between age at onset and IAA-levels. The clinical significance of these autoantibodies for the pathogenesis and clinical course of the disease is nevertheless still controversial [13-21].

In this study comprising 194 newly diagnosed diabetic children and adolescents the incidence of IAA was $31.4 \%$, which is about the same as we have recently reported in a smaller group of patients [18]. The results confirm that IAA occur more often in young children [16], which may reflect a more active immune response in these individuals or an immature clearing process for immune-complexes [20]. Our data support the view that IAA are not significant from the clinical point of view at the presentation of Type 1 diabetes, since we found no association between the presence of

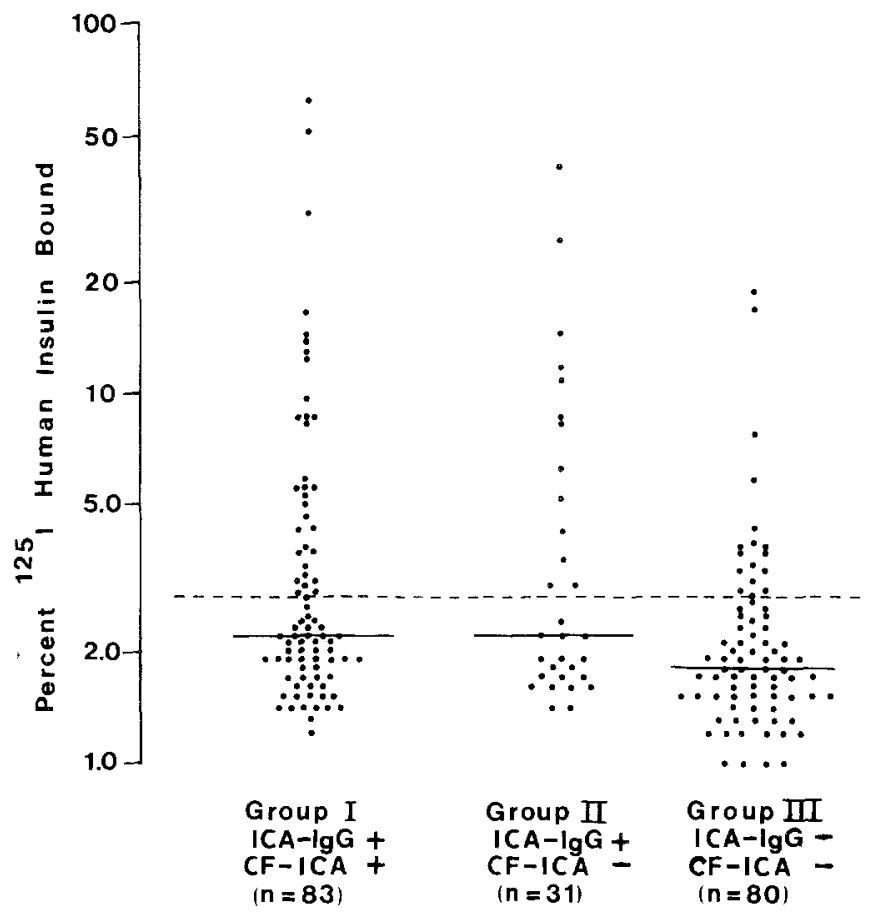

Fig. 1. Distribution of insulin autoantibodies (\% binding) in sera of children with Type 1 diabetes grouped according to their ICA-IgG and CF-ICA status. Comparison between the groups; I vs III, $p<0.001$; II vs III, $p<0.01$, I vs II, NS. $(--=$ limit for IAA-positivity, $-=$ median)

IAA and the degree of metabolic decompensation. This assumption is corroborated by a recent finding indicating that the formation of IAA starts relatively late in the prediabetic period [20]. In a recent study on the possible influence of IAA on the clinical course of Type 1 diabetes after diagnosis [21] we did not observe any differences between IAA-positive and negative patients in the incidence or duration of clinical remission, metabolic control, endogenous insulin secretion or daily insulin dose over the first year. On the other hand, there are data indicating that antibodies developing against exogenous insulin have a deleterious effect on the residual B-cell function [23, 24]. Antibodies to exogenous insulin, however, generally occur at considerably higher titres than IAA.

The HLA risk antigens $\mathrm{D}(\mathrm{R}) 3$ and/or $\mathrm{D}(\mathrm{R}) 4$ may play an important role in the pathogenesis of Type 1 diabetes by controlling the susceptibility of the pancreatic B cells to viral insults [10] and autoimmune destructive processes [11]. In a previous report we found an association between IAA and HLA-Dw4 but not DR4 [18]. In the present study Dw4 was more frequently observed in IAA-positive children than in IAA-negative ones, although the difference was not significant. There are several reports suggesting no association between IAA and the high risk antigens in the DR region in newly diagnosed diabetic patients $[16,18]$ or in unaffected identical twins of diabetic patients [15]. On the other hand, in one study all 22 IAA- 
Table 3. Clinical and laboratory characteristics (mean \pm SEM, unless otherwise indicated) in groups of children with newly diagnosed Type 1 (insulin-dependent) diabetes classified according to insulin autoantibodies (IAA) status and islet cell antibody (ICA) status (ICA-IgG $=$ conventional ICA, CF-ICA = complement-fixing ICA)

\begin{tabular}{|c|c|c|c|c|}
\hline & $\begin{array}{l}\text { Group I } \\
\text { IAA+ } \\
\text { ICA-IgG+ } \\
\text { CF-ICA+ } \\
(n=32)\end{array}$ & $\begin{array}{l}\text { Group II } \\
\text { IAA and/or } \\
\text { ICA-IgG+ } \\
(n=98)\end{array}$ & $\begin{array}{l}\text { Group III } \\
\text { IAA- } \\
\text { ICA-IgG- } \\
\text { CF-ICA- } \\
(n=64)\end{array}$ & $\begin{array}{l}\text { Level of } \\
\text { significance }\end{array}$ \\
\hline Sex (male/female) & $13 / 19$ & $56 / 42$ & $39 / 25$ & $\begin{array}{l}\text { I vs II and III, } \\
p<0.05\end{array}$ \\
\hline Duration of symptoms (wecks) & $2.3 \pm 0.4$ & $3.5 \pm 0.5$ & $3.5 \pm 0.6$ & $\begin{array}{l}\text { I vs II and III, } \\
p<0.05\end{array}$ \\
\hline Blood glucose $(\mathrm{mmol} / \mathrm{l})$ & $22.0 \pm 1.5$ & $21.2 \pm 0.9$ & $20.0 \pm 1.1$ & NS \\
\hline $\mathrm{pH}$ & $7.32 \pm 0.02$ & $7.32 \pm 0.01$ & $7.34 \pm 0.01$ & NS \\
\hline Base excess $(\mathrm{mmol} / 1)$ & $-7.6 \pm 1.6$ & $-7.5 \pm 0.8$ & $-5.9 \pm 1.0$ & NS \\
\hline Ketoacidosis, $n(\%)$ & $11 / 28(39.3)$ & $36 / 87(41.4)$ & $18 / 60(30.0)$ & NS \\
\hline $\operatorname{IgG}>15$ EIU, $(\%)$ & $14 / 30(46.7)$ & $50 / 96(52.1)$ & $40 / 64(62.5)$ & NS \\
\hline IgM $>20$ EIU, $n(\%)$ & $4 / 30(13.3)$ & $16 / 96(16.7)$ & $10 / 64(15.6)$ & NS \\
\hline $\mathrm{IgA}>20 \mathrm{EIU}, n(\%)$ & $6 / 30(20.0)$ & $21 / 96(21.9)$ & $18 / 64(28.1)$ & NS \\
\hline Dw3 $3 / x, n(\%)$ & $5 / 26(19,2)$ & $6 / 81(7.4)$ & $13 / 52(25.0)$ & II vs III, $p<0.01$ \\
\hline Dw $4 / x, n(\%)$ & $10 / 26(38.5)$ & $32 / 81(39.5)$ & $17 / 52(32.7)$ & NS \\
\hline Dw3/Dw4, $n(\%)$ & $6 / 26(23.1)$ & $11 / 81(13.6)$ & $10 / 52(19.2)$ & NS \\
\hline
\end{tabular}

$\mathrm{NS}=$ not significant

positive subjects out of the 245 non-diabetic relatives of patients with Type 1 diabetes had HLA-DR3 and/or DR4 [19]. Our observation of subjects with the HLA haplotype A9Bw16 having lower IAA levels than others is of interest with regard to an earlier finding of an association between this haplotype and the ICA-negative form of Type 1 diabetes [25].

Available data on the assiciation between IAA and ICA are contradictory [13, 16-19], and we could not find any relation between IAA and ICA-IgG or CFICA in a previous series comprising 60 children with newly diagnosed diabetes [18]. The present data on 194 diabetic patients reveal an association between the occurrence of IAA and ICA-IgG (Table 1). In addition, the patients positive for ICA-IgG had significantly higher IAA titres than the ICA-negative ones (Fig.1). Accordingly, the present results substantiate the previously reported association between IAA and ICA-IgG $[13,17,19]$. CF-ICA have been found to be associated with IgG-class IAA but not with those of the IgM-class [17]. In our earlier study we did not see any relation between IAA and CF-ICA. In the present survey there was no significant difference in the distribution of CFICA positive individuals between IAA positive and negative, but the CF-ICA positive children had higher IAA levels than the negative patients. Previously, we did not observe any difference in the duration of symptoms between IAA-positive and negative subjects with newly diagnosed Type 1 diabetes [18]. The present findings provide evidence for a shorter symptomatic period in children positive for both IAA and ICA compared to those being negative for one or all autoantibodies (Table 3). This finding can be interpreted as supporting the suggestion that the production of IAA is a late phenomenon in the prediabetic period [20]. McEvoy et al. [20] have previously reported that girls have higher titres of IAA at diagnosis than boys. We observed that girls were more often contemporaneously positive for both IAA and ICA than boys. On the other hand, Type 1 diabetes is somewhat more common in males than in females.

The role of viruses in the aetiology of Type 1 diabetes has been under extensive research for decades. The present hypothesis is that viruses act at least in some subjects as triggers, inducing destruction of the B cells in one way or another [26]. Some strains of the Coxsackie viruses $[2,4-7]$ and the mumps virus $[8-10]$ have in particular been regarded as aetiological factors in Type 1 diabetes. The relationship between IAA and virus antibodies has not been evaluated earlier in detail, although there is one report indicating no association between IAA and Coxsackie-B virus antibody titres at the clinical manifestation of diabetes [16]. Organ-specific antibodies have been studied in relation to virus antibodies, suggesting a relation between CoxsackieIgM-class antibodies and CF-ICA [7]. King et al. [4] found Coxsackie-B virus specific $\operatorname{IgM}$ antibodies in $6 / 15$ patients with both ICA-IgG and CF-ICA 
2-16 weeks after diagnosis. IAA of IgM class have been detected in non-diabetic children during a 6-month follow-up period after acute viral infections [27], but neither ICA-IgG nor CF-ICA appeared during that time period after mumps infections. That finding is in line with our observation in newly diagnosed diabetic children of no positive relation between ICA and antibodies to the mumps virus. In the present study we found an inverse relation between ICA-IgG and mumps virus specific class IgG antibodies and between CF-ICA and Coxsackie-B4 virus specific class IgA antibodies (Table 2), but no other associations could be detected between the viral antibodies and the autoantibodies (IAA and ICA). The individuals with a recent mumps virus infection had higher IAA levels than the others. This indicates that a mumps infection may trigger an autoimmune destruction of the pancreatic $B$ cell reflected in the formation of autoantibodies to insulin. On the other hand the production of IAA soon after mumps may well be related to mumps itself as previously suggested [27]. The frequencies of IAA and ICA positivity did not show any seasonal variation.

The major findings in this cross-sectional study are the inverse association between autoantibodies and age and the positive relationship between IAA and ICA-IgG at the clinical manifestation of Type 1 diabetes, suggesting IAA to be a marker of autoimmune Bcell damage. The lower incidence of Coxsackie-B4 and mumps virus-specific antibodies in patients with ICA (Table 2) and the inverse relation between autoantibodies and age fit in with the hypothesis that autoimmune mechanisms may play a more active role in young children while environmental factors may be of greater importance in older children contracting the disease. This diversity could be an additional indicator of the heterogeneity in the aetiology and pathogenesis of Type 1 diabetes.

Acknowledgements. We thank Drs. A.Hakulinen, T.Huupponen, A.-L. Mäkelä and A. Rilva for their collaboration in the collection of specimens and Ms. S. Anttila and Ms. T.Halonen for their skilful technical assistance. This work was supported by the Alma and K.A.Snellman Foundation, Oulu, Finland (J.K.), the Foundation for Diabetes Research in Finland (J. K., H. H.), Novo Research Institute, Bagsvaerd, Denmark (M.K.) and Nordisk Insulinfond, Denmark (J.I.).

\section{References}

1. Eisenbarth GS (1986) Type 1 diabetes mellitus: a chronic autoimmune disease. $N$ Engl J Med 314: 1360-1368

2. Palmer JP, Cooney MK, Ward RH, Hansen JA, Brodsky JB, Ray CG, Crossley JR, Asplin CM, Williams RH (1982) Reduced Coxsackie antibody titers in Type 1 diabetic patients presenting during an outbreak of Coxsackie-B3 and B4 infection. Diabetologia 22: 426-429

3. Dahlquist $G$, Blom L, Holmgren $G$, Hägglöf B, Larsson $Y$, Sterky G, Wall S (1985) The epidemiology of diabetes in Swedish children $0-14$ years - a six-year prospective study. Diabetologia 28 : 802-808
4. King ML, Bidwell P, Shaikh A, Banatvala JE (1983) Coxsackie virus specific IgM responses in children with insulin dependent (juvenile-onset, Type 1) diabetes mellitus. Lancet I: 1397-1399

5. Hyöty H, Huupponen T, Kotola L, Leinikki P (1986) Humoral immunity against viral antigens in Type 1 diabetes: altered $\operatorname{IgA}$. class immune response against Coxsackie-B4 virus. Acta Pathol Microbiol Immunol Scand [C] 94: 83-88

6. Banatvala JE, Schernthaner G, Schober E, De Silva LM, Bryant J, Borkenstein M, Brown D, Menser MA (1985) Coxsackie B, mumps, rubella and cytomegalovirus specific $\operatorname{IgM}$ responses in patients with juvenile-onset diabetes mellitus in Britain, Austria and Australia. Lancet II: $1409-1412$

7. Schernthaner G, Scherbaum W, Borkenstein M, Banatvala JE, Bryant J, Schober E, Mayr WR (1985) Coxsackie-B-virus-specific IgM responses, complement-fixing islet-cell antibodies, HLADR-antigens and C-peptide secretion in insulin-dependent diabetes mellitus. Lancet II: $630-632$

8. Hyöty H, Huupponen T, Leinikki P (1985) Humoral immunity against viral antigens in insulin-dependent diabetes mellitus (IDDM): altered IgA class immune response against mumps virus. Clin Exp Immunol 60: 139-144

9. Ratzmann KP, Strese J, Witt S, Berling H, Keilacker H, Michaelis $D(1985)$ Mumps infection and insulin-dependent diabetes mellitus (IDDM). Diabetes Care 7: 170-173

10. Brüserud O, Jervell J, Thorsby E (1985) HLA-DR3 and -DR4 control T-lymphocyte responses to mumps and Coxsackie B4-virus. Studies on patients with Type I (insulin-dependent) diabetes and healthy subjects. Diabetologia 28: 420-426

11. Bruining GJ, Molenaar JL, deJongh BM, Aarsen RSR, Visser HKA (1985) Prediction of Type 1 diabetes mellitus - a report on three cases. Eur J Pediatr 143: 175-178

12. Srikanta S, Ganda OP, Jackson RA, Brink SJ, Fleischnick E, Yunis E, Alper C, Soeldner JS, Eisenbarth GS (1984) Pre-Type 1 (insulin-dependent) diabetes: common endocrinological course despite immunological and immunogenetic heterogeneity. Diabetologia 27: 146-148

13. Srikanta S, Ricker AT, McCulloch DK, Soeldner JS, Eisenbarth GS, Palmer JP (1986) Autoimmunity to insulin, beta cell dysfunction and development of insulin-dependent diabetes mellitus. Diabetes 35: 139-142

14. Palmer JP, Asplin CM, Clemons P, Lyen K, Tatpati O, Raghu PK, Paquette TL (1983) Insulin antibodies in insulin-dependent diabetics before insulin treatment. Science 222: 1337-1339

15. Wilkin T, Armitage M, Casey C, Pyke DA, Hoskins PJ, Rodier M, Diaz JL, Leslie RDG (1985) Value of insulin autoantibodies as serum markers for insulin-dependent diabetes mellitus. Lancet I: $480-482$

16. Arslanian SA, Becker DJ, Rabin B, Atchison R, Eberhardt M, Cavender D, Dorman J, Drash AL (1985) Correlates of insulin antibodies in newly diagnosed children with insulin-dependent diabetes before insulin therapy. Diabetes 34: 926-930

17. Dean BM, Becker F, McNally JM, Tarn AC, Schwartz G, Gale EAM, Bottazzo GF (1986) Insulin autoantibodies in the pre-diabetic period: correlation with islet cell antibodies and development of diabetes. Diabetologia 29: 339-342

18. Karjalainen J, Knip M, Mustonen A, Ilonen J, Åkerblom HK (1986) Relation between insulin antibody and complement-fixing islet cell antibody at clinical diagnosis of IDDM. Diabetes 35 : 620-622

19. Atkinson MA, MacLaren NK, Riley JW, Winter WF, Fisk DD, Spillar RP (1986) Are insulin autoantibodies markers for insulindependent diabetes mellitus? Diabetes 35: 894-898

20. McEvoy RC, Witt ME, Ginsberg-Fellner F, Rubinstein P (1986) Anti-insulin antibodies in children with Type 1 diabetes mellitus, genetic regulation of production and presence at diagnosis before insulin replacement. Diabetes 35: 634-641

21. Karjalainen J, Knip M, Mustonen A, Åkerblom HK (1988) Insulin autoantibodies at the clinical manifestation of Type 1 (insulindependent) diabetes - a poor predictor of clinical course and antibody production to exogenous insulin. Diabetologia 31: 129-133 
22. Bottazzo GF, Dean BM, Gorsuch AN, Cudworth AG, Doniach D (1980) Complement-fixing islet-cell antibodies in Type 1 diabetics: possible monitors of active beta-cell damage. Lancet I: $668-672$

23. Ludvigsson J (1984) Insulin antibodies in diabetic children treated with monocomponent porcine insulin from the onset: relationship to B-cell function and partial remission. Diabetologia 26: $138-141$

24. Mäkelä A-L, Åkerblom HK, Käär M-L, Heding LG, Knip M, Mäkelä $P(1985)$ Insulin antibodies in diabetic children related to the age of patients and serum C-peptide values. Two years' follow-up results of a randomized study. Diabetes Res Clin Practice [Suppl] 1: 255

25. Mustonen A, Ilonen J, Åkerblom HK, Tiilikainen A (1982) An islet cell antibody negative form of insulin-dependent diabetes mellitus (IDD) associated with HLA antigens A9 and Bw16. Clin Exp Immunol 48: 213-217
26. Toniolo A, Onodera T (1984) Viruses and Diabetes. In: Andreani D, DiMario U, Federlin KF, Heding LG (eds) Immunology in Diabetes. Kimpton Medical Publications, London, pp 71-93

27. Bodansky HJ, Dean BM, Bottazzo GF, Grant PJ, McNally J, Hambling MH, Wales JK (1986) Islet-cell antibodies and insulin autoantibodies in association with common viral infections. Lancet II: $1351-1353$

Received: 8 September 1987

and in revised form: 31 December 1987

Dr. Jukka Karjalainen

Department of Paediatrics

University of Oulu

SF-90220 Oulu

Finland 